\title{
All Together Now: Supporting Immigrants and Refugees Through Collaboration
}

Jen Vanek, World Education, Inc.; Heide Spruck Wrigley, LiteracyWork International; Erik Jacobson, Montclair State University; and Janet Isserlis, Rhode Island Adult Education Professional Development Center

\begin{abstract}
The United States needs strong collaboration among adult educators and all social service agencies that support the linguistic, economic and civic integration of refugees and immigrants. Such collaboration can make possible holistic support required to create linkages between English language education and other non-educational support services. We provide examples of several interagency collaborative projects across the United States. Further, we argue that such collaboration is essential to mitigate the limitations of current adult basic education policy, which falls short of supporting linguistic integration of English language learners at the lowest proficiency levels, implicitly prioritizing workforce development programming best suited for higher-level learners. We layout policy recommendations for the local, state, and federal levels and map out benefits of working as partners in advocacy with agencies that support resettlement and integration of adult refugee and immigrant learners.

Author Note: The authors would like to acknowledge the work of the Open Door Collective (ODC) and, in particular, its Immigrant and Refugee Education and Integration Issues Group, which initially spurred the collaboration that resulted in this paper. ODC, a program of Literacy Minnesota, is a national volunteer group of professionals working in adult education, public libraries, community health, workforce development, criminal justice reform, digital inclusion, and other social services. ODC members believe that adult basic skills education and lifelong learning programs can help reduce poverty and open the doors of opportunity for everyone to healthier, more prosperous and satisfying lives.
\end{abstract}

During times of political uncertainty, support for the linguistic, economic and civic integration of refugees and immigrants is vulnerable to shifts in public opinion and policy. At the time of writing, the U.S. executive administration has, for example, contributed to the notion that immigrants from particular parts of the world are outsiders to be feared, rather than neighbors offering important social and economic contributions. Furthermore, given the potential for the extreme poverty caused by displacement to become intergenerational (Kallenbach et al., 2013), it is essential that immigrant communities are provided with focused and intensive support. 
New types and levels of collaboration are required to push back against anti-immigrant and antirefugee discourse and to ensure that immigrants receive the resources they need to support learning and integration into communities and workplaces. Collaboration aimed at sustaining well-coordinated programming, support services and advocacy can create a powerful synergy, amplifying the reach of all organizations involved (Kallenbach et al., 2013). Partnerships may start as local or statewide entities consisting of different providers working to support immigrants and refugees. Such joint efforts can better analyze significant gaps in existing services, identify needed programming, and engage in advocacy campaigns that are responsive to the needs of newcomers.

\section{Supporting the Linguistic, Economic, and Civic Integration of Refugees and Immigrants}

Given the complexity of the language and literacy skills necessary to thrive in the United States today, immigrants and refugees need sustained, high-quality, and timely language instruction. In many, if not most, cases, they also need case management support in order to cope with turbulence in their lives. However, the current adult basic education (ABE) system, as defined by the Workforce Innovation and Opportunity Act (WIOA) $)^{1}$, offers only narrow support for certain vulnerable learners, such as individuals with limited English and low levels of prior education. Additionally, the outcomes used to evaluate programs receiving funds available under WIOA may have little to do with the lived experience of newcomers. For many, the earning of secondary credential or matriculation into postsecondary schooling (two of the WIOA core measures) are distant goals.

Although states are free to establish secondary measures related to education, these are not reported to the federal government, and programs might feel pressure to enroll only learners whose goals align with WIOA core measures, leaving beginning-level learners and adults not in the workforce underserved. Furthermore, the lack of a coordinated immigrant integration effort at the federal level means that partnerships, rather than individual programs, are better positioned to remedy this gap in services (Colbern \& Ramakrishnan, 2016). It is, therefore, incumbent upon states, municipalities, and local programs to work together to expand opportunities for holistic support and English language and literacy programming.

Such collaboration is not easy to establish and maintain, but strong examples are starting to emerge. For example, the English Plus Integration (EPI) initiative created by the Migration Policy Institute's (MPI) National Center on Immigrant Integration Policy aims to connect communitybased organizations with providers associated with public health, education (K-12 and adults), early childhood education, and social services. Stakeholders involved in these efforts include recognized leaders and experts from immigrant and refugee communities, state and local governments, and the adult education, immigrant integration, and early childhood education fields. MPI has partnered with Unidos in several states to develop locally adapted

1 WIOA defines how federal funding is used to support adult English language programming. Federal funding, supplemented by state money, supports English Language Acquisition (ELA) programs as part of free ABE system. Over 1.5 million learners in 2015-2016 (the last year for which aggregate participation data is available), $46 \%$ of whom enrolled in ELA programs (Adult Education and Family Literacy Act of 1998: Annual Report to Congress, Program Year 2015 - 16, 2019, p. 3) 
versions of EPI to be piloted starting in mid2020. One promising implementation model is Lifting Immigrant Family Trajectories, an initiative centered around a series of workshops on integration topics with interwoven supports for digital literacy and English language acquisition. Through joint planning, partners deliver locally integrated workshops to low income immigrants and refugees new to English and who need information on how to navigate systems such as financial services, medical care, and educational services.
Guidance for developing partnerships can be found in Establishing and Developing ESOL Local Partnerships: An Effective Practice Guide (2019). (See: https://www.learningandwork. org.uk/wp-content/uploads/2019/04/ESOLPartnership-Guide.pdf) Though written to support local collaboration in the Great Britain, the guide provides a timely and applicable sketch of how interagency partnerships form and several illustrative examples. The Networks for Integrating New Americans (NINA) framework offers an overview and examples illustrating the strength of a network approach to building the

\section{Examples of Collaboration Around Adult English Acquisition and Integration}

The following examples illustrate the range of partnerships that expand educational opportunities for immigrant learners.

Seattle: Ready to Work is a municipal approach to supporting linguistic, social, and economic integration for immigrants and refugees new to English by involving the mayor and city council and Seattle city agencies: the Human Services Department, the Office of Economic Development and the Office of Immigrant and Refugee Affairs. These municipal players have partnered with a state and federally-funded adult education provider, Literacy Source, and Asian Counseling and Referral Services, a community-based organization, to offer beginning English language classes and provide employment and transition services with multicultural staff and interpreters proficient in the many languages spoken in the community and in the class, including Somali, Amharic, Chinese, Vietnamese (https://acrs.org/). Program success rests on case management provided by well-trained bilingual and culturally competent staff, most from the learners' home communities.

(See: https://www.nationalskillscoalition.org/news/blog/ready-to-work-seattle-creates-newon-ramp-for-immigrant-english-learners)

Alliance for Language Learners' Integration, Education and Success (ALLIES), a coalition of adult schools, community colleges, and community-based organizations in Silicon Valley relies on partnerships to achieve "collective impact." ALLIES and its partners work at the grassroots level to support concrete initiatives and at state and national levels to advocate for supportive policies. Formed specifically as a collaboration of programs and agencies serving 
English language learners, ALLIES partners have developed a multisector initiative to make the regional adult education system more transparent to clients and also facilitate learner transitions across programs or along an integrated pathway involving different agencies. (See: http://www.allies4innovation.org/).

Make the Road New York and its sister programs in New Jersey, Pennsylvania and Connecticut demonstrate the value of community-based organizations and advocacy groups coming together around issues relevant to the immigrant members of the organization. For example, Make the Road New York was successful in advocating for better treatment of grocery store workers. Such a victory was possible because Make the Road coordinated efforts with other advocates for workers' and immigrants' rights and because students enrolled in English classes were key resources in advocacy events (such as marches and rallies). The English classes and advocacy efforts support and reinforce each other, with pressing issues becoming part of the ESOL curriculum and students taking to streets to add their voices to calls for justice. (See: http://www.maketheroad.org).

\section{English Innovations (EI), OneAmerica and Partnership for New Americans. The} English Innovations Initiative, originally funded by the Bill and Melinda Gates Foundation, presents a national model connecting agencies and schools across the United States through efforts that take place outside the federally and state funded adult education system.

Led by OneAmerica, an advocacy group in Seattle, eight host sites focus on community engagement and teach English and digital literacy to support immigrant integration. Host sites share a common curriculum (adaptable to local priorities and varying student groups), a common goal (individual and community empowerment) and a common instructional approach (intentional teaching and engaged learning). The program is now administered by the National Partnership for New Americans, an umbrella coalition of statewide immigrant rights coalitions, including local programs that combine service delivery such as adult education classes with community organizing. (See: https://weareoneamerica.org/speakyour-language)

capacity of local education and service providers in the United States (Kallenbach et al., 2013).

\section{Advocacy in Support of Policy Shifts}

Beyond coordinating local resources, agencies working together might also consider collaboration in advocacy in support of policy changes that strategically link a broad spectrum of organizational support for newcomers and ensure that all learners have access to the language and literacy instruction they need.

\section{Federal Level}

Available funding for $\mathrm{ABE}$ in the United States has steadily declined overtime, now at roughly $10 \%$ per student compared to funding levels in 1965 (Jacobson, 2017), making it harder to serve a very diverse community of potential learners. 
Given WIOA's workforce perspective, the goal of these federal-level recommendations is to increase educational opportunities for learners with little to no proficiency in English through additional funding and expanded access to existing programs.

\section{Recommendation: Increase Funding for Family}

Literacy Programs. Lack of investment in parents and their learning creates the potential for poverty caused by relocation to develop into intergenerational poverty (Park, McHugh, \& Katsiaficas, 2016). A high percentage of refugees are women and children; in 2015, nearly half of the 69,920 admitted refugees to the United States were children, 33,335 were women, and $35 \%$ of the women were principal applicants (U.S. Department of Homeland Security, 2016). However, funding for family literacy has been gutted, severely limiting access to adult education for mothers of young children who need access to English language services (Park et al., 2016). Funding for programs that support immigrant and refugee parents and families should be included in both federal and state funded programs.

\section{Recommendation: Integrate Foundational} English Classes with Workforce Training. WIOA provides for workforce development training services at "one-stop job centers" funded through the Department of Labor (WIOA, Title I) and intended to prioritize provision of service to "basic skills deficient" adults, which includes English learners who may not be prepared to participate in training due to their language skills. Currently, WIOA-driven performance constraints (e.g., employment and wage gain outcomes) create a disincentive for job training programs to enroll ELLs and still meet their performance goals. To provide more equitable access, Title 1 funded programs in American Job Centers (formerly known as "one-stop job centers") should be incentivized to integrate English instruction with job skills training, rather than referring English learners to general English classes first for a sequential program of learning English, then job training. Such career focused on-ramps could allow learners, for whom it is appropriate, to develop basic English and occupational skills simultaneously.

\section{State and Local Level}

These recommendations for advocacy at the state and local level can help ensure that available funding, as defined by WIOA, is used to support relevant programming to the widest range of learners possible in any given community.

\section{Recommendation: Support Access to Relevant} Curricula. Refugees and immigrants should be provided with focused language acquisition services that are flexible and tailored to meet individual learners' needs. Advocacy at the state-level might include a call to prioritize the secondary measures allowed within WIOA (e.g., citizenship, voting, involvement in community and their childrens' education). Educational providers should work with learners and collaborating agencies to develop contextualized and relevant curricula leading to these outcomes by addressing a range of students' goals, roles and responsibilities, including citizenship and civic participation, immigrants' and refugees' roles as parents, and their needs as lifelong learners. Students need to be prepared to advocate for themselves, their families and their communities in multiple contexts. This means that taking action for educational, economic and legal justice should be part of the curriculum.

\section{Recommendation: Open Access to Education.} At the time of writing, the Deferred Action for Childhood Arrivals (DACA) program had been terminated by the Trump administration and its final status yet undetermined, pending a decision 
from the U.S. Supreme Court. DACA allowed young adults brought to the United States as children (and without legal status) to work and study without fear of deportation. Though DACA's future is uncertain, agencies should continue to advocate for maintaining and extending programs that offer work authorization for immigrant youth who came to the United States as children. It is likely that any success in securing such authorization will require a high school diploma or participation in adult basic education programs; this means that more of such classes need to be readily available. Funding should also be available to support ELA programs for adults who may need English to meet legalization requirements once comprehensive immigration reform becomes a reality (Wrigley, 2015).

\section{A Call for Unified Advocacy}

Advocacy efforts and expanded learning opportunities are especially important in light of the rhetoric and actions of our highest-ranking public officials. Strident interpretations and enforcement of deportation policies have violated human and civil rights and created a climate of fear in refugee and immigrant communities. In the United States, a great many organizations touch the lives of immigrants and refugees and, as we assert, innovative collaboration exists. Adult educators, advocacy groups, resettlement agencies, social services and immigrant-serving community-based organizations need to work together to assure equitable access to programs offering relevant language instruction and fair distribution of federal and state education funds for refugees and immigrants. Such collaboration can help us find common ground and meet a common goal: linguistic, economic, civic and social integration that benefits newcomers while at the same time strengthening communities. 


\section{References}

Colbern, A. \& Ramakrishnan (2016). State policies on immigrant integration: An examination of best practices and policy diffusion. University of California Riverside, School of Public Policy. Retrieved from https://www. immigrationresearch.org/report/other/state-policiesimmigrant-integration-examination-best-practices-andpolicy-diffusion

Jacobson, E. (2017). The Workforce Investment and Opportunity Act: New policy developments and persistent issues. In A. Belzer (Ed.), New Directions for Adult and Continuing Education, 155, pp. 19 - 27.

Kallenbach, S., Lee, K. S., Downs-Karkos, S., Taylor, M. B., Brennan, J., \& Nash, A. (2013). Adult education and immigrant integration: Networks for integrating New Americans (NINA). World Education, Inc. Retrieved from https://lincs.ed.gov/publications/pdf/NINA theoretical-framework.pdf

Learning and Work Institute. (2019). Establishing and developing ESOL local partnerships: An effective practice guide. Retrieved from https://www. learningandwork.org.uk/resource/resources-to-supportthe-development-of-local-esol-partnerships/
Park, M., McHugh, M., \& Katsiaficas, C. (2016). Serving immigrant families through two-generation programs: Identifying family needs and responsive program approaches. Migration Policy Institute. https://www. migrationpolicy.org/sites/default/files/publications/ DualGenerationLearning-2016-FINAL.pdf

U.S. Department of Education. (2019). Adult Education and Family Literacy Act of 1998: Annual report to Congress, Program Year 2015 - 16. Retrieved from https://www2.ed.gov/about/offices/list/ovae/pi/AdultEd/ aefla-rtc-py2015-508-final.pdf

U.S. Department of Homeland Security. (2016). Table 15. Refugee arrivals by relationship to principal applicant and sex, age, and marital status: Fiscal year 2015. Retrieved from https://www.dhs.gov/immigrationstatistics/yearbook/2015/table15

Wrigley, H. S. (2015). Green card English: New possibilities and enduring challenges in US Immigration. In J. Simpson \& A. Whiteside (Eds.), Adult language education and migration: Challenging agendas in policy and practice (pp. 225-243). New York, NY: Routledge. 